\title{
Biochemical and cultural characteristics of mineral-solubilizing Acinetobacter sp. DDP346
}

\author{
Hee Sook Kim ${ }^{1} \cdot$ Song Min Lee ${ }^{1} \cdot \mathrm{Ka}-Y o o n \mathrm{Oh}^{1} \cdot \mathrm{Ji}$-Youn Kim${ }^{1}$. \\ Kwang Hui Lee ${ }^{1} \cdot$ Sang-Hyeon Lee ${ }^{2} \cdot$ Jeong Su Jang ${ }^{1}$ (i)

\section{미네랄 가용화능을 갖는 Acinetobacter sp. DDP346의 생화학적 및 배양학적 특성}

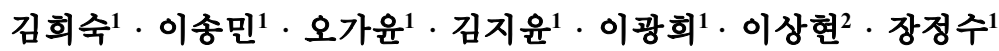

Received: 22 July 2021 / Accepted: 23 September 2021 / Published Online: 31 December 2021

(C) The Korean Society for Applied Biological Chemistry 2021

\begin{abstract}
In this study, to select strains suitable as microbial agent from among rhizosphere microorganisms present in rhizosphere soil and roots, the mineral solubilization ability, antifungal activity against 10 types of plant pathogenic fungi, and plant growthpromoting activity of rhizosphere microorganisms were evaluated. As a result, DDP346 was selected because it has solubilization ability of phosphoric acid, calcium carbonate, silicon, and zinc; nitrogen fixing ability; production ability of siderophore, indole-3acetic acid, and aminocyclopropane-1-carboxylate deaminase; and antifungal activity against seven types of plant pathogenic fungi. DDP346 showed a 99.9\% homology with Acinetobacter pittii DSM 21653 (NR_117621.1); phylogenetic analysis also revealed a close relationship with Acinetobacter pittii based on the $16 \mathrm{~S}$ rRNA base sequence. The growth conditions of DDP346 were identified as temperatures in the range of $10-40{ }^{\circ} \mathrm{C}, \mathrm{pH}$ in the range of 5-11, and salt concentrations in the range of $0-5 \%$. In addition, a negative correlation coefficient $\left(\mathrm{r}^{2}=-0.913, p<0.01\right)$
\end{abstract}

Jeong Su Jang $(\bowtie)$

E-mail: jeongsu25@naver.com

${ }^{1}$ Food Research Center, Angel Co., Ltd., Busan 46988, Republic of Korea

${ }^{2}$ Department of Pharmaceutical Engineering, Silla University, Busan 46958, Republic of Korea

This is an Open Access article distributed under the terms of the Creative Commons Attribution Non-Commercial License (http://creativecommons. org/licenses/by-nc/3.0/) which permits unrestricted non-commercial use, distribution, and reproduction in any medium, provided the original work is properly cited. was shown between $\mathrm{pH}$ change and the solubilized phosphoric acid content of Acinetobacter sp. DDP346, and this is assumed to be due to the organic acid generated during culture. Consequently, through the evaluation of its mineral solubilization ability, antifungal activity against plant pathogenic fungi, and plant growth-promoting activity, the potential for the utilization of Acinetobacter sp. DDP346 as a multi-purpose microbial agent is presented.

Keywords Acinetobacter sp. · Microbial agent - Mineral solubilization $\cdot$ Plant growth promoting rhizobacteria

서 론

무분별한 화학비료 및 농약의 사용은 토양의 비옥도를 감소시 켰으며 이로 인해 식물의 생장저해와 더불어 농업의 생산성이 떨어지는 결과를 초래하였다. 이외에도 화학비료 및 농약의 사 용으로 인한 환경과 식품 안전상의 문제에 대한 대처 수단으로 써 미생물 제제가 주목받아 왔지만 아직까지도 비료 시장에서 미생물 제제는 극히 일부분을 차지하고 있다. 현재 판매되고 있 는 주요 미생물 제제는 질소 고정 비료와 인산 가용화 비료로 각각 $80,14 \%$ 정도의 점유율을 차지하고 있다[1-2].

식물의 생장과 발달에 필요한 대부분의 영양소들은 토양에서 불용성의 형태로 존재하고 있어서 식물이 이용하는 데 어려움 이 있는데, 이러한 문제를 해결하기 위해서 식물은 뿌리 삼출 물을 분비함으로써 근권의 미생물을 이용한다. 식물 생장 촉진 
근권 미생물(PGPR, plant growth promoting rhizobacteria)은 식물의 근권에 존재하면서 식물 생장을 촉진시키는 미생물로 직 접적으로는 질소고정능, siderophore 생성능, 미네랄 가용화능 및 환경스트레스와 관련된 indole-3-acetic acid (IAA)와 aminocyclopropane-1-carboxylate (ACC) deaminase를 생성함으로써 식물의 생장을 도와주는 것으로 알려져 있다[3-4]. 질소는 식물 과 미생물을 포함한 모든 생물체의 생장에 필수적인 중요한 영 양소 중 하나로 대부분의 PGPR은 질소 고정능을 가지고 있는 것으로 알려져 있다[5]. 또한, 철이 결핍된 조건에서 $\mathrm{PGPR}$ 은 철을 흡수하기 위해 siderophore라는 철 이온 결합 물질을 분비 하여 철의 이용률을 높임으로써 식물의 생장을 촉진할 뿐만 아 니라 식물 병원성 곰팡이와의 철 경쟁을 통해 식물 병원성 곰 팡이의 생장을 억제하여 방제 활성을 나타내는 것으로 알려져 있다[6]. 이외에도 PGPR에 의해 생성되는 여러 유기산과 유기 화합물은 불용성 인산, 규소, 아연과 같은 미네랄을 가용화하여 식물에 유효도(availability)를 증가시킴으로써 식물의 생장에 도 움을 주는 것으로 알려져 있다[7].

PGPR은 식물 뿌리 주변에 서식하면서 식물에 의해 삼출되는 트립토판을 이용하여 IAA를 생성하며, 생성된 IAA는 ACC를 합 성함으로써 식물 내에 에틸렌 수준을 증가시켜 식물의 생장에 도움을 준다. 그러나, IAA 및 외부 환경 스트레스에 의해 생성 되는 에틸렌의 수준이 과도하게 증가하면 뿌리 신장의 저해 및 노화와 세포의 손상이 가속화되어 식물의 생장을 저해한다. 이 러한 문제는 근권 미생물이 ACC deaminase를 생성함으로써 에 틸렌의 전구체인 $\mathrm{ACC}$ 를 ammonia와 $\alpha$-ketobutyrate로 분해하여 식물 내의 에틸렌 수준을 감소시킬 수 있으며 이를 통해 외부 환경 스트레스로부터 식물의 생장에 도움을 줄 수 있다[5]. 간접 적으로는 영양분의 경쟁, 암모니아, cyanogens, alcohols, 세포벽 분해 효소, 이차대사산물 등을 통하여 생물학적 또는 비생물학 적 스트레스를 완화시켜 줌으로써 식물 생장에 도움을 준다[8]. 따라서, 미네랄 영양분 공급과 식물 생장 촉진, 식물 병원성 곰 팡이와 세균에 대한 항진균 활성 및 항균 활성을 동시에 가진 균주를 선별하기 위해서 근권 토양과 뿌리로부터 미생물을 분리 하여 미네랄 가용화능, 식물 병원성 곰팡이와 세균에 대한 항진 균 활성 및 항균 활성, 식물 생장 촉진 활성을 평가하였다.

\section{재료 및 방법}

\section{미생물 분리}

토양 및 뿌리 채취는 부산 다대포(DDP) 해변, 부산 삼락공원 $(\mathrm{SN})$ 의 갈대밭, 제주도 해변(ANG) 및 토마토 밭(ANG)에서 채 취하였다. 채취한 토양시료 $1 \mathrm{~g}$ 을 멸균된 생리식염수에 연속으 로 희석하여 $\left(10^{-1}-10^{-7}\right)$ 현탁 후 bennet agar (BA, glucose 10 $\mathrm{g} / \mathrm{L}$, peptone $2 \mathrm{~g} / \mathrm{L}$, beef extract $1 \mathrm{~g} / \mathrm{L}$, yeast extract $1 \mathrm{~g} / \mathrm{L}$, agar $15 \mathrm{~g} / \mathrm{L}$ ), tryptic soy agar (TSA, Difco ${ }^{\mathrm{TM}}$ ), humic-vitamin (HV) agar (humic acid $1 \mathrm{~g} / \mathrm{L}, \mathrm{KCl} 0.5 \mathrm{~g} / \mathrm{L}, \mathrm{Na}_{2} \mathrm{HPO}_{4} 0.5 \mathrm{~g} / \mathrm{L}$, $\mathrm{MgSO}_{4} \quad 0.5 \mathrm{~g} / \mathrm{L}, \quad \mathrm{CaCO}_{3} 0.02 \mathrm{~g} / \mathrm{L}, \quad \mathrm{FeSO}_{4} 0.02 \mathrm{~g} / \mathrm{L}, \quad \mathrm{V}_{\mathrm{B}}$ stock solution $1 \mathrm{~g} / \mathrm{L}$, agar $15 \mathrm{~g} / \mathrm{L}$ ) plate에 도말하여 균을 분리하였다. 채취한 뿌리는 근권 미생물의 분리를 위해서 계면활성제인 Tween 80과 표백제인 perchloric acid (1\%)를 처리하여 표면 미생물을 제거한 후 $\mathrm{BA}, \mathrm{TSA}, \mathrm{HV}$ 배지에 $30{ }^{\circ} \mathrm{C}$ 에서 2 일간
배양하여 순수 분리하였다[9]. 토양의 염농도(\%)는 전기전도계 (STARTER 3100C, OHAUS, Seoul, Korea)를 이용하여 전기전 도도 $(\mathrm{EC})$ 를 측정한 후 계산식 $($ 염농도 $(\%)=\mathrm{EC}(\mathrm{ds} / \mathrm{m}) \times 0.064)$ 에 따 라 환산하였다.

\section{미네랄 가용화능}

인산과 탄산칼슘, 규소, 아연 가용화능을 확인하기 위해서 각각 Pikovskaya agar (calcium phosphate $5.0 \mathrm{~g} / \mathrm{L}$, yeast extract $0.5 \mathrm{~g} / \mathrm{L}$, glucose $10 \mathrm{~g} / \mathrm{L}, 10 \mathrm{CaO} \cdot 3 \mathrm{P}_{2} \mathrm{O}_{5} \cdot \mathrm{H}_{2} \mathrm{O} 5 \mathrm{~g} / \mathrm{L}, \quad\left(\mathrm{NH}_{4}\right)_{2} \mathrm{SO}_{4}$ $0.5 \mathrm{~g} / \mathrm{L}, \quad \mathrm{KCl} \quad 0.02 \mathrm{~g} / \mathrm{L}, \quad \mathrm{MgSO}_{4} \cdot 7 \mathrm{H}_{2} \mathrm{O} \quad 0.1 \mathrm{~g} / \mathrm{L}, \quad \mathrm{MnSO}_{4} \cdot 5 \mathrm{H}_{2} \mathrm{O}$ $0.0001 \mathrm{~g} / \mathrm{L}, \mathrm{FeSO}_{4} \cdot 7 \mathrm{H}_{2} \mathrm{O} 0.0001 \mathrm{~g} / \mathrm{L}$, agar $15 \mathrm{~g} / \mathrm{L}, \mathrm{pH}$ 6.8) 배 지[10], Deveze-Bruni agar (D-glucose $5 \mathrm{~g} / \mathrm{L}$, yeast extract $1.0 \mathrm{~g} / \mathrm{L}$, peptone $1.0 \mathrm{~g} / \mathrm{L}, \mathrm{K}_{2} \mathrm{HPO}_{4} 0.4 \mathrm{~g} / \mathrm{L}, \mathrm{MgSO}_{4} \quad 0.01 \mathrm{~g} / \mathrm{L}$, $\mathrm{NaCl} 5 \mathrm{~g} / \mathrm{L},\left(\mathrm{NH}_{4}\right)_{2} \mathrm{SO}_{4} 0.05 \mathrm{~g} / \mathrm{L}, \mathrm{CaCO}_{3} 5 \mathrm{~g} / \mathrm{L}$, agar $15 \mathrm{~g} / \mathrm{L}$, $\mathrm{pH}$ 6.8) 배지[11], silicate agar (D-glucose $10 \mathrm{~g} / \mathrm{L}$, magnesium trisilicate $2.5 \mathrm{~g} / \mathrm{L}$, agar $15 \mathrm{~g} / \mathrm{L}, \mathrm{pH} 6.8$ ) 배지[12] 및 Trisminimal salt (D-glucose $10 \mathrm{~g} / \mathrm{L}$, tris- $\mathrm{HCl} \quad 6.06 \mathrm{~g} / \mathrm{L}, \quad \mathrm{NaCl}$ $4.68 \mathrm{~g} / \mathrm{L}, \quad \mathrm{KCl} 1.49 \mathrm{~g} / \mathrm{L}, \quad \mathrm{NH}_{4} \mathrm{Cl} 1.07 \mathrm{~g} / \mathrm{L}, \quad \mathrm{Na}_{2} \mathrm{SO}_{4} \quad 0.43 \mathrm{~g} / \mathrm{L}$, $\mathrm{MgCl}_{2} \cdot 2 \mathrm{H}_{2} \mathrm{O} \quad 0.2 \mathrm{~g} / \mathrm{L}, \quad \mathrm{CaCl}_{2} \cdot 2 \mathrm{H}_{2} \mathrm{O} \quad 0.03 \mathrm{~g} / \mathrm{L}, \quad \mathrm{Zn}_{3}\left(\mathrm{PO}_{4}\right)_{2} \cdot 4 \mathrm{H}_{2} \mathrm{O}$ $1.9982 \mathrm{~g} / \mathrm{L}$, agar $15 \mathrm{~g} / \mathrm{L}, \mathrm{pH}$ 7.0) 배지[13]를 이용하였다. 배지 중앙에 cork borer를 이용하여 잘라낸 뒤, 선별된 균주의 상등 액을 주입하여 $30{ }^{\circ} \mathrm{C}$ 에서 4 일간 배양하면서 clear zone의 형성 유무를 확인하였다.

\section{식물 병원성 곰팡이에 대한 항진균 활성}

선별된 균주들의 식물 병원성 곰팡이에 대한 항진균 활성을 조 사하기 위하여 Alternaria alternata KACC 40019, Botrytis cinerea KACC 40573, Colletotrichum acutatum KACC 40042, Corynespora cassiicola KACC 44719, Fusarium oxysporum f.sp. lactucae KACC 42795, Fusarium solani KACC 41092, Fusarium tricinctum KACC 42097, Phytophthora capsici KACC 40180, Rhizoctonia solani AG-2-1 KACC 40124, Sclerotinia sclerotiorum KACC 41065 등 총 10종을 사용하였 다. 식물 병원성 곰팡이에 대한 항진균 활성은 $\mathrm{PDA}$ 에서 agar diffusion법을 이용하여 분리 균주를 접종하여 5 일간 검정 균주 와 $25^{\circ} \mathrm{C}$ 에서 대치 배양하였다. 식물 병원성 곰팡이와 미생물 간의 거리를 측정하여 억제율로 환산하였다[14].

$$
\text { 억제율 }(\%)=((\mathrm{R}-\mathrm{r}) / \mathrm{R}) * 100
$$

$\mathrm{R}$ : 식물병원성 곰팡이와 분리 균주 사이의 거리 $(\mathrm{mm})$ $\mathrm{r}$ : 식물병원성 곰팡이의 성장 반경 $(\mathrm{mm})$

\section{식물 병원성 세균에 대한 항균 활성}

선별된 균주들의 식물 병원성 세균에 대한 항균 활성을 조사하기 위하여 Pectobacterium carotovorum KACC 10227, Pseudomonas syringae pv. sesami KACC 18460, Pseudomonas syringae pv. syringae KACC 18392, Xanthomonas campestris KACC 16358, Xanthomonas euvesicatoria KACC 18723 등 총 5종을 사용하였다. 식물 병원성 세균에 대한 항균 활성은 $\mathrm{TSA}$ 에서 agar diffusion법을 이용하여 분리 균주를 접종하여 1 일간 배양 하였다. 그 후 clear zone 형성 유무에 따라 항균 활성 정도를 평가하였다. 


\section{질소고정능, siderophore 생성능}

질소 고정능을 확인하기 위해서 질소원이 결핍된 nitrogen free bromothymol blue (NFB) 배지를 이용하였다. NFB 배지에 $10 o p$ 를 이용하여 전배양된 균주를 접종하여 $30^{\circ} \mathrm{C}$ 에서 4 일간 배 양하면서 배지 색이 푸른색으로 변한 경우를 양성으로 판정하 였다[15]. Siderophore 생성능을 확인하기 위해서 chrome azurol $\mathrm{S}$ blue agar plate assay 방법을 이용하였으며, 선별된 균주를 접종하여 $30{ }^{\circ} \mathrm{C}$ 에서 4 일간 배양한 후 orange halo zone 형성 유무에 따라 siderophore 생성능을 확인하였다[16].

\section{IAA 생성능}

IAA 생성능을 확인하기 위해서 전배양된 균주를 King's B 배 지(proteose peptone $20 \mathrm{~g} / \mathrm{L}, \mathrm{K}_{2} \mathrm{HPO}_{4} 2.5 \mathrm{~g} / \mathrm{L}, \mathrm{MgSO}_{4} 6 \mathrm{~g} / \mathrm{L}$, glycerol $15 \mathrm{~mL} / \mathrm{L}$, tryptophan $1 \mathrm{~g} / \mathrm{L}, \mathrm{pH} 7.2$ )에 $0.1 \%$ 를 접종하 여 $30{ }^{\circ} \mathrm{C}$ 에서 2 일간 배양하였다. 배양액은 원심분리 후 상층액 을 분리하여, Salkowski's reagent $\left(35 \% \mathrm{HClO}_{4} 50 \mathrm{~mL}, 0.5 \mathrm{M}\right.$ $\left.\mathrm{FeCl}_{3} 1 \mathrm{~mL}\right)$ 와 1:2 (v/v)의 비율로 혼합한 다음, 분홍색으로 발 색되는 동안 상온에서 30 분간 정치하였다. 이후, 분광광도계 (Spectrophotometer, Multiskan GO, Thermo Scientific, Vantaa, Finland)를 이용하여 $530 \mathrm{~nm}$ 에서 흡광도를 측정하였다. 표준물 질로 $\mathrm{IAA}$ 를 이용하여 작성된 검량선에 따라 시료의 농도를 환 산하였다[17].

\section{ACC deaminase 생성능}

Barnawal 등[18]의 방법에 따라 ACC deaminase 활성을 확인하 였다. 선별된 균주를 $\mathrm{TSB}$ 배지에 접종하여 $30^{\circ} \mathrm{C}$ 에서 2 일간 배 양한 뒤 원심분리하여 균체를 회수하였다. 회수한 균체는 $\mathrm{DF}$ salt 배지 $\left(\mathrm{KH}_{2} \mathrm{PO}_{4} 4 \mathrm{~g} / \mathrm{L}, \mathrm{Na}_{2} \mathrm{HPO}_{4} 6 \mathrm{~g} / \mathrm{L}, \mathrm{MgSO}_{4} \cdot 7 \mathrm{H}_{2} \mathrm{O} 0.2 \mathrm{~g} / \mathrm{L}\right.$, $\mathrm{FeSO}_{4} 0.001 \mathrm{~g} / \mathrm{L}, \mathrm{H}_{3} \mathrm{BO}_{3} 0.00001 \mathrm{~g} / \mathrm{L}, \mathrm{MnSO}_{4} \cdot \mathrm{H}_{2} \mathrm{O} 0.00001 \mathrm{~g} / \mathrm{L}$, $\mathrm{ZnSO}_{4} \quad 0.00007 \mathrm{~g} / \mathrm{L}, \quad \mathrm{CuSO}_{4} 0.00005 \mathrm{~g} / \mathrm{L}, \mathrm{MoO}_{3} 0.00001 \mathrm{~g} / \mathrm{L}$, glucose $2 \mathrm{~g} / \mathrm{L}, \mathrm{C}_{6} \mathrm{H}_{12} \mathrm{O}_{7} 2 \mathrm{~g} / \mathrm{L}, \mathrm{C}_{6} \mathrm{H}_{8} \mathrm{O}_{7} 2 \mathrm{~g} / \mathrm{L}, \mathrm{pH}$ 7.3)로 두 차례 세척한 후 $3 \mathrm{mM} \mathrm{ACC}$ 가 첨가된 $\mathrm{DF}$ salt 배지에 접종하 여 $30{ }^{\circ} \mathrm{C}$ 에서 5 일간 배양하였다. 이후 $600 \mathrm{~nm}$ 에서 흡광도를 측 정하여 분리 균주의 생장 정도를 통해 ACC deaminase 생성을 확인하였다.

\section{최종 선별주의 $16 \mathrm{~S}$ rRNA 유전자 분석}

$16 \mathrm{~S}$ rRNA 유전자 분석을 (주)솔젠트(Solgent Co., Ltd., Daejeon, Korea)에 의뢰하여 분석하였으며, 유전자 증폭을 위해 universal primer인 27F (5'-AGA GTT TGA TCC TGG CTC AG-3')와 1492R (5'-GGT TAC CTT GTT ACG ACT T-3') 를 사용하였다.

\section{생장 조건 확인}

기후, 토양 환경 등 다양한 조건에서 생육 조건을 확인하기 위 해서 TSB 배지를 이용하여, 배양온도 $\left(0-55^{\circ} \mathrm{C}\right)$, 배양온도별 $\mathrm{pH}$ (4-13) 및 염농도 $0-20 \%(\mathrm{w} / \mathrm{v})$ 에서 생육능을 확인하였으며, 성장 곡선은 분광광도계를 이용하여 $600 \mathrm{~nm}$ 에서 흡광도를 측정하였다.

\section{인산 가용화능 측정}

NBRIP 배지(glucose $10 \mathrm{~g} / \mathrm{L}, \mathrm{Ca}_{3}\left(\mathrm{PO}_{4}\right)_{2} 5 \mathrm{~g} / \mathrm{L}, \mathrm{MgCl}_{2} \cdot 6 \mathrm{H}_{2} \mathrm{O} 5$ $\mathrm{g} / \mathrm{L}, \quad \mathrm{MgSO}_{4} \cdot 7 \mathrm{H}_{2} \mathrm{O} \quad 0.25 \mathrm{~g} / \mathrm{L}, \mathrm{KCl} 0.2 \mathrm{~g} / \mathrm{L},\left(\mathrm{NH}_{4}\right)_{2} \mathrm{SO}_{4} 0.1 \mathrm{~g} / \mathrm{L}$, $\mathrm{pH}$ 7.0)에 접종한 뒤 24시간 간격으로 배양액으로부터 유리된 인산을 Lee와 Song[19]의 방법을 응용하여 측정하였다. 원심분 리하여 얻은 상등액 $1 \mathrm{~mL}$ 를 vanado-molybdophosphoric acid 반응용액(solution A: ammonium molybdate $25 \mathrm{~g}, \mathrm{dH}_{2} \mathrm{O} 400$ $\mathrm{mL}$, solution $\mathrm{B}$ : ammonium metavanadate $1.25 \mathrm{~g}, \mathrm{dH}_{2} \mathrm{O} 300$ $\mathrm{mL}, \mathrm{HNO}_{3} 250 \mathrm{~mL}$; solution $\mathrm{A}$ 와 solution $\mathrm{B}$ 를 혼합한 뒤 최종 부피가 $1,000 \mathrm{~mL}$ 가 되도록 $\mathrm{dH}_{2} \mathrm{O}$ 를 첨가) $1 \mathrm{~mL}$ 와 혼합하여 30 ${ }^{\circ} \mathrm{C}$ 에서 30 분간 반응시킨 뒤 $470 \mathrm{~nm}$ 에서 흡광도를 측정하였다.

\section{pH, 잔류당 측정}

배양이 진행됨에 따라 생성되는 유기산에 의한 $\mathrm{pH}$ 변화와 glucose 함량 변화를 관찰하기 위해 $\mathrm{pH}$ 와 잔류당을 측정하였다. $\mathrm{pH}$ 는 $\mathrm{pH}$ meter (ST2100-F, OHAUS, Seoul, Korea)를 이용하 여 측정하였으며, 배지 내 잔류당 분석은 DNS (3,5-dinitrosalicylic acid)법을 이용하여 측정하였다[20]. 상등액과 DNS를 1:3으로 혼합한 뒤 $100{ }^{\circ} \mathrm{C}$ 에서 15 분간 반응시켰다. 이후 실온에서 냉각 시킨 뒤 분광광도계를 이용하여 $550 \mathrm{~nm}$ 에서 흡광도를 측정하였 다. 잔류당 측정의 표준물질로는 glucose (Junsei Chemical Co., Ltd.)를 이용하였다.

\section{가수분해 효소활성 측정}

Amylase 활성은 Miller [21]의 방법을 응용하였으며, 배양 상등 액과 $1 \%$ starch solution을 $1: 1(\mathrm{v} / \mathrm{v})$ 로 상온에서 3 분 동안 반 응시킨 후 $\mathrm{DNS}$ 와 혼합하였다. 이후 $100^{\circ} \mathrm{C}$ 에서 15 분 동안 열 처리 한 뒤 얼음에 냉각시킨 후 분광광도계를 이용하여 540 $\mathrm{nm}$ 에서 흡광도를 측정하였다. Cellulase와 xylanase의 활성은 Shin과 Cho [22]의 방법을 응용하였으며, 배양 상등액과 각 $1 \%$ CMC (carboxymethyl cellulose) solution과 1\% xylan solution 을 $1: 1(\mathrm{v} / \mathrm{v})$ 로 혼합하여 $50^{\circ} \mathrm{C}$ 에서 10 분간 반응시켰다. 이후 $\mathrm{DNS}$ 를 첨가하여 $100{ }^{\circ} \mathrm{C}$ 에서 열처리 한 뒤 얼음에 냉각시킨 후 분광광도계를 이용하여 $540 \mathrm{~nm}$ 에서 흡광도를 측정하였다. Protease 활성은 $\mathrm{Oh}$ 등[23]의 방법을 응용하여 측정하였다. 배 양 상등액과 $0.65 \%$ casein 용액을 $1: 5(\mathrm{v} / \mathrm{v})$ 로 혼합한 뒤 37 ${ }^{\circ} \mathrm{C}$ 에서 10 분간 반응시켰다. 이후 $0.44 \mathrm{M}$ trichloroacetic acid를 첨가하여 $37{ }^{\circ} \mathrm{C}$ 에서 10 분간 단백질을 응고시킨 뒤 $0.45 \mu \mathrm{m}$ filter를 이용하여 여과한 후 여과액과 $1 \mathrm{~N}$ Folin-Ciocalteu's phenol reagent를 혼합하여 $37^{\circ} \mathrm{C}$ 에서 30 분간 반응시켰다. 흡광 도는 $660 \mathrm{~nm}$ 에서 측정하였다. 또한 DDP346이 생산하는 여러 효소활성을 확인하기 위해서 API ZYM kit (bioMérieux, France)를 이용하였으며, 제조사의 매뉴얼에 따라 진행하였다.

\section{통계분석}

모든 분석은 3 회 이상 수행하였으며, 평균 \pm 표준편차(Mean $\pm \mathrm{SD}$ ) 로 표현하였다. 평균값의 유의한 차이는 SPSS (version 20.0 for Windows, SPSS Inc., Chicago, IL, USA)를 이용한 일원배 치 분산분석(one-way ANOVA)의 Duncan's multiple range test 를 사용하였다. 유의성 검증은 신뢰구간 $p<0.05$ 에서 분석하였 다. $\mathrm{pH}$ 변화와 가용화된 인산 함량 간의 상관관계는 Pearson's correlation coefficient $(p<0.01)$ 로 분석하였다. 
Table 1 Summary of information on isolates, samples of soil, and root

\begin{tabular}{|c|c|c|c|c|c|}
\hline Isolates & Isolation location & Isolation source & $\mathrm{pH}$ & $\begin{array}{c}\mathrm{NaCl} \text { concentration } \\
(\%)\end{array}$ & $\begin{array}{l}\text { Isolation } \\
\text { medium }\end{array}$ \\
\hline ANG5 & Jeju, around the beach & Wild herb root & 7.0 & 0.060 & $\mathrm{BA}$ \\
\hline ANG37 & Busan, tomato & Soil & 6.8 & 0.221 & $\mathrm{HV}$ \\
\hline DDP68 & Busan, around the beach & Soil & 6.8 & 0.182 & BA \\
\hline DDP77 & Busan, around the beach & Soil & 3.2 & 0.985 & $\mathrm{HV}$ \\
\hline DDP304 & Busan, around the beach & Wild herb root & 3.2 & 0.985 & $\mathrm{BA}$ \\
\hline DDP346 & Busan, around the beach & Wild herb root & 6.8 & 0.245 & TSA \\
\hline DDP390 & Busan, around the beach & Wild herb root & 6.8 & 0.245 & $\mathrm{HV}$ \\
\hline DDP398 & Busan, around the beach & Wild herb root & 7.0 & 0.084 & TSA \\
\hline DDP406 & Busan, around the beach & Wild herb root & 5.8 & 0.497 & TSA \\
\hline DDP458 & Busan, around the beach & Wild herb root & 7.0 & 0.084 & $\mathrm{HV}$ \\
\hline DDP469 & Busan, around the beach & Wild herb root & 7.0 & 0.084 & $\mathrm{HV}$ \\
\hline SN74 & Busan, park & Soil & 6.8 & 0.142 & $\mathrm{HV}$ \\
\hline SN128 & Busan, park & Reed root & 5.8 & 0.598 & $\mathrm{BA}$ \\
\hline
\end{tabular}

\section{결과 및 고찰}

\section{미생물의 분리}

근권(rhizosphere) 토양으로부터 미생물을 분리하기 위해서 부산 다대포 해변(DDP), 부산 삼락공원( $\mathrm{SN})$ 의 갈대밭, 제주도 해변 (ANG) 및 토마토 밭(ANG)에서 토양과 뿌리를 채취하여 미생 물을 분리하였으며, 그중에서도 형태학적으로 서로 다른 특징을 가진 13종을 선별하였다(Table 1). 이후 분리된 균주들의 미네 랄 가용화능, 식물 병원성 곰팡이와 세균에 대한 항진균 활성 및 항균 활성, 식물 생장 촉진 활성을 조사하였다.

\section{미네랄 가용화능}

인산, 탄산칼슘, 규소, 아연 가용화능을 확인한 결과, ANG37, $\mathrm{DDP} 77, \mathrm{DDP} 346, \mathrm{DDP} 398, \mathrm{DDP} 406$ 균주에서 4종의 미네랄 가용화능을 확인할 수 있었다(Table 2). 대부분의 미네랄 가용 화는 미생물에 의해 생성되는 2-ketogluconic acid, polysaccharides, alkali 등과 같은 많은 유기 화합물에 의해 일어나는 것으로 알 려져 있다[7]. 따라서, 분리된 균주들에 의해 다양한 미네랄 가 용화 물질이 생성되는 것으로 추정되며, 인산, 탄산칼슘, 규소, 아연 등을 공급해줌으로써 대사 과정, 세포벽과 세포막의 구조 적 안정성, 식물의 생장과 발달, 질병에 대한 저항성 등 다양한 영향을 줄 수 있을 것으로 판단된다[24-26]. 향후 작물재배를 통해 불용성 미네랄 가용화능을 가진 균주를 이용하여 미네랄 의 흡수에 따른 식물 생장과 발달에 미치는 영향에 대한 후속 연구가 필요할 것으로 판단된다. 이후 연구부터는 4 종의 미네 랄에 대해 가용화능을 가진 5균주를 선별하여 진행하였다.

\section{식물 병원성 곰팡이와 세균에 대한 항진균 활성 및 항균 활성 조사}

대표적인 식물 병원성 곰팡이 10 종과 식물 병원성 세균 5 종을 시험균으로 사용하여 조사한 분리주의 항진균 활성 및 항균 활 성 결과를 Table 3 에 나타내었다. 항진균과 항균 활성 확인 결 과, $\mathrm{DDP} 77, \mathrm{DDP} 398, \mathrm{DDP} 406$ 균주들에서는 활성을 확인할 수
Table 2 Activities of mineral solubilization from isolated strains

\begin{tabular}{ccccc}
\hline \hline & \multicolumn{4}{c}{ Mineral solubilization ${ }^{1)}$} \\
\cline { 2 - 5 } Strains & Phosphate & $\mathrm{CaCO}_{3}$ & $\mathrm{Mg}_{2} \mathrm{Si}_{3} \mathrm{O}_{8}$ & $\mathrm{Zn}_{3}\left(\mathrm{PO}_{4}\right)_{2} \cdot$ \\
\cline { 2 - 5 } & + & + & + & - \\
\hline ANG5 & + & ++ & ++ & + \\
ANG37 & + & - & - & - \\
DDP68 & + & + & + & + \\
DDP77 & + & + & - & - \\
DDP304 & - & + & ++ & + \\
DDP346 & ++ & + & + & - \\
DDP390 & + & + & + & + \\
DDP398 & ++ & + & + & + \\
DDP406 & ++ & + & + & - \\
DDP458 & + & - & - & - \\
DDP469 & + & - & - & - \\
SN74 & + & + & ++ & - \\
SN128 & - & + & & +
\end{tabular}

1) ++ : strongly positive $(>15 \mathrm{~mm}),+$ : positive $(\leq 15 \mathrm{~mm}),-$ : negative

없었으며, ANG37 균주는 Fusarium tricinctum과 Pseudomonas syringae pv. sesami, Xanthomonas campestris에서 약하게 활성 이 보였다. DDP346 균주는 7종의 식물 병원성 곰팡이에 대해 서 항진균 활성을 보였으며, 그 중에서도 Colletotrichum acutatum과 Corynespora cassiicola에 대해서 높은 항진균 활성 을 나타내었다. 또한, P. syringae에 대해서도 약한 항균 활성을 나타내었다. 이러한 항진균 활성과 항균 활성은 근권 미생물에 의해 생성되는 항생물질, 휘발성 물질, siderophore, 세포 외 효 소 등에 의한 것으로 알려져 있다[27]. 따라서, DDP346은 7종 의 식물 병원성 곰팡이에 대해 항진균 활성과 항균 활성을 가 짐으로써 검은무늬병, 잿빛곰팡이, 탄저병, 잎마름병, 시듦병, 역 병 및 세균성 점무늬병 등을 유발하는 곰팡이 및 세균에 취약 한 작물에 적용 가능할 것으로 판단된다. 
Table 3 Antifungal activity of isolated strains against phytopathogenic fungi and bacteria

\begin{tabular}{|c|c|c|c|c|c|c|}
\hline & Strains & ANG37 & DDP77 & DDP346 & DDP398 & DDP406 \\
\hline \multirow{10}{*}{$\begin{array}{c}\text { Antifungal } \\
\text { activities (\%) }\end{array}$} & Alternaria alternata & - & - & $19.80 \pm 2.01$ & - & - \\
\hline & Botrytis cinerea & - & - & $22.93 \pm 2.61$ & - & - \\
\hline & Colletotrichum acutatum & - & - & $43.67 \pm 3.02$ & - & - \\
\hline & Corynespora cassiicola & - & - & $53.17 \pm 3.48$ & - & - \\
\hline & Fusarium oxysporum & - & - & - & - & - \\
\hline & Fusarium solani & - & - & $22.17 \pm 1.96$ & - & - \\
\hline & Fusarium tricinctum & $10.37 \pm 1.86$ & - & $27.40 \pm 2.08$ & - & - \\
\hline & Phytophthora capsici & - & - & $9.67 \pm 0.29$ & - & - \\
\hline & Rhizoctonia solani & - & - & - & - & - \\
\hline & Sclerotinia sclerotiorum & - & - & - & - & - \\
\hline \multirow{5}{*}{$\begin{array}{l}\text { Antibacterial } \\
\text { activities }(\mathrm{cm})\end{array}$} & Pectobacterium carotovorum & - & - & - & - & - \\
\hline & Pseudomonas syringae pv. sesami & $1.12 \pm 0.06$ & - & $0.94 \pm 0.04$ & - & - \\
\hline & Pseudomonas syringae pv. syringae & - & - & - & - & - \\
\hline & Xanthomonas campestris & $0.82 \pm 0.04$ & - & - & - & - \\
\hline & Xanthomonas euvesicatoria & - & - & - & - & - \\
\hline
\end{tabular}

${ }^{1)}$ Data are mean \pm SD of at least three replicates

\section{질소 고정능과 siderophore 생성능}

질소 고정능과 siderophore 생성능을 측정한 결과, 5 균주에서 모 두 질소 고정능과 siderophore 생성능을 확인할 수 있었다. 그 중에서도 DDP346은 가장 높은 질소 고정능을 나타내었다(Table 4). 질소 비료는 사용한 비료의 $50 \%$ 이하만 식물에 효과적으로 흡수되고 나머지는 휘발성 분해로 인하여 손실된다는 단점이 있 다[28]. 따라서, 본 연구 결과 5 균주 모두 질소 고정능과 siderophore 생성능을 가짐으로써 질소와 철 이용률을 높여 식 물 생장에 도움을 줄 수 있을 것으로 추정되며, 지속성이 낮은 화학 비료의 대체제로 활용이 가능할 것으로 판단된다. 또한 siderophore의 경우에는 식물 병원성 곰팡이와의 철 경쟁을 통 해 병원체의 생장과 병해에 영향을 미치는 것으로 알려져 있으 며[6], 이를 통해 DDP346에 의해 생성된 siderophore가 7종의 식물 병원성 곰팡이에 대한 항진균 활성을 나타내는 데에 일부 영향을 미친 것으로 추정된다.

\section{IAA 생성능, ACC deaminase 생성능 조사}

본 연구는 환경스트레스와의 연관성을 조사하기 위해서 IAA와 $\mathrm{ACC}$ deaminase 생성능을 측정하였다. 먼저, 식물 생장 호르몬 으로 알려진 IAA 측정 결과, $5.80-64.15 \mu \mathrm{g} / \mathrm{mL}$ 의 IAA 생성능 을 확인할 수 있었으며, 그 중에서도 DDP346, DDP398 및 $\mathrm{DDP} 406$ 균주에서 비교적 높은 IAA 생성능을 확인할 수 있었 다. ACC deaminase 생성능은 5균주에서 비슷한 수준으로 나타 내었다(Table 4). Danish 등[29]은 건조 스트레스 조건하에서 $\mathrm{ACC}$ deaminase 활성을 가진 균주를 접종하여 옥수수를 재배한 결과, shoot length와 shoot dry weight가 각각 최대 1.5 배와 1.4 배까지 증가한 것으로 보고하였다. 또한, 염 스트레스 조건 에서 식물에 PGPR 균주를 처리했을 때, 식물 내의 $\mathrm{Na}^{+}$이온 공급을 줄여 $\mathrm{Na}^{+} / \mathrm{K}^{+}$의 비율을 조절함으로써 염 스트레스를 완 화시켜 주는 것으로 알려져 있다[30]. 따라서, 본 연구에서 IAA 와 ACC deaminase 생성능을 가진 균주가 외부 환경 스트레스 로부터 이온의 항상성을 유지해 줌으로써 식물의 생장에 도움
Table 4 Activities of nitrogen fixation, siderophore production, IAA production, and ACC deaminase production from isolated strains

\begin{tabular}{ccccc}
\hline \hline Strains & $\begin{array}{c}\text { Nitrogen } \\
\text { fixation }^{1)}\end{array}$ & $\begin{array}{c}\text { Siderophore } \\
\text { production }^{2)}\end{array}$ & $\begin{array}{c}\text { IAA } \\
\text { production } \\
(\mu \mathrm{g} / \mathrm{mL})^{3)}\end{array}$ & $\begin{array}{c}\text { ACC } \\
\text { deaminase } \\
\text { production }^{4)}\end{array}$ \\
\hline ANG37 & + & + & $12.10 \pm 0.81^{\mathrm{b}}$ & + \\
DDP77 & + & + & $5.80 \pm 0.18^{\mathrm{a}}$ & + \\
DDP346 & ++ & + & $59.10 \pm 1.42^{\mathrm{c}}$ & + \\
DDP398 & + & + & $57.63 \pm 1.98^{\mathrm{c}}$ & + \\
DDP406 & + & + & $64.15 \pm 0.52^{\mathrm{d}}$ & + \\
\hline
\end{tabular}

${ }^{11}$ Nitrogen fixation activity was determined by color change of NFB broth ${ }^{2}$ Siderophore production was confirmed by orange halo zone. +: positive (>15 mm)

${ }^{3}$ Data are mean \pm SD of at least three replicates. Means with different letter (a-d) indicate significant differences at $p<0.05$

${ }^{4)} \mathrm{ACC}$ deaminase production was determined by growth on medium with ACC as sole nitrogen source. + : positive (absorbance at $600 \mathrm{~nm} \geq 0.1$ )

Table 5 Enzyme activity of DDP $346^{1)}$

\begin{tabular}{|c|c|c|}
\hline & Characteristics & DDP346 \\
\hline \multirow{4}{*}{$\begin{array}{l}\text { Extracellular } \\
\text { enzyme } \\
(\mathrm{mg} / 100 \mathrm{~mL})^{1)}\end{array}$} & Amylase $^{2)}$ & $16.91 \pm 2.51$ \\
\hline & Cellulase $^{3)}$ & $10.49 \pm 1.97$ \\
\hline & Protease ${ }^{4)}$ & $19.70 \pm 1.75$ \\
\hline & Xylanase $^{5)}$ & $49.85 \pm 3.51$ \\
\hline \multirow{5}{*}{ API ZYM ${ }^{6)}$} & Esterase (C4) & ++ \\
\hline & Esterase (C8) & + \\
\hline & Leucine arylamidase & +++ \\
\hline & Valine arylamidase & + \\
\hline & Naphtol-AS-BI-phosphohydrolase & + \\
\hline
\end{tabular}

${ }^{1)}$ Data are mean \pm SD of at least three replicates. In each assay, the standard substances are maltose $\mathrm{e}^{2)}$, glucose $\mathrm{e}^{3)}$, tyrosine ${ }^{4)}$ and D-xylose ${ }^{5)}$, respectively

${ }^{6}+++$ : strongly positive, ++ : positive, + : weakly positive 

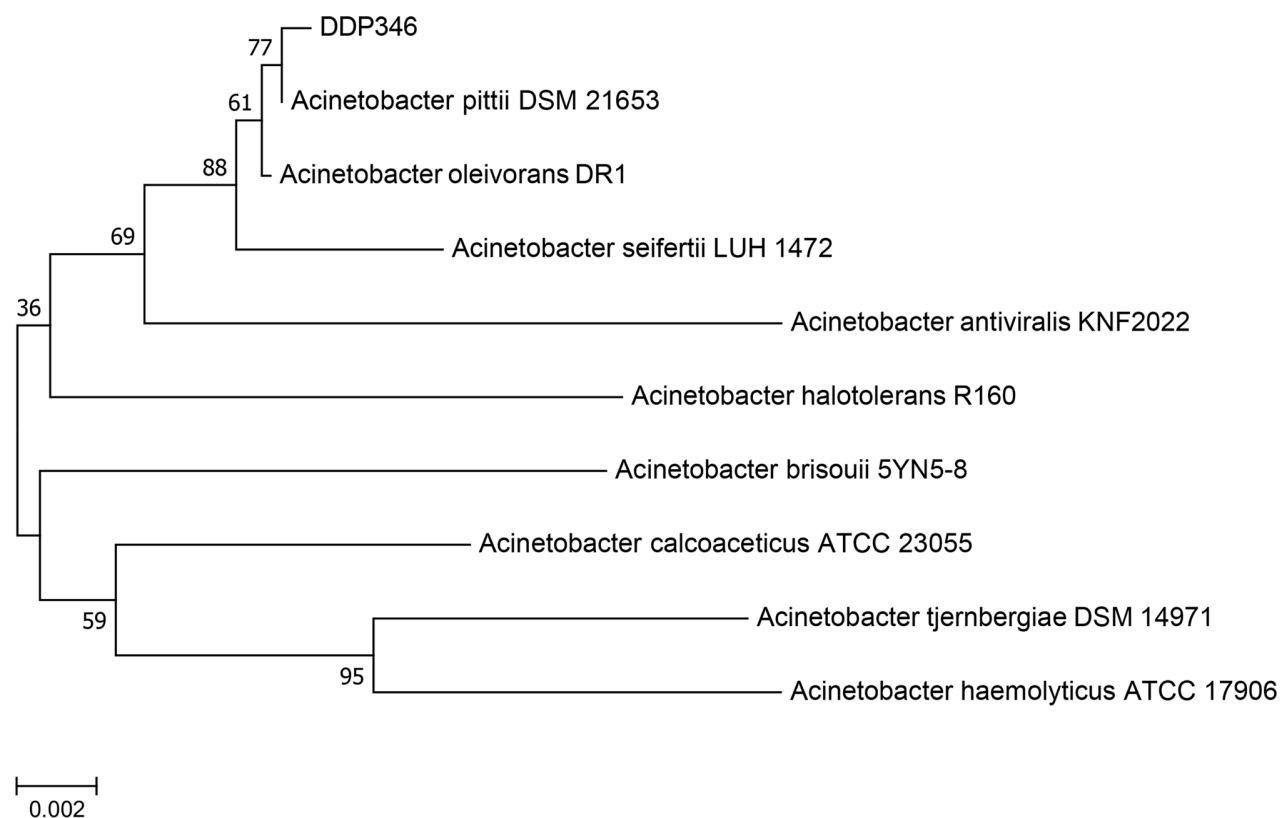

Fig. 1 Phylogenetic tree based on nearly 16S rRNA gene sequences. Numbers at the nodes are percentage bootstrap values (1,000 replicates). Bar, 0.002 substitutions per nucleotide position

을 줄 수 있을 것으로 추정되며, 향후 환경 스트레스 조건에서 식물의 생장과 발달에 미치는 영향을 알아보기 위해서 작물 재 배를 통한 후속 연구가 필요할 것으로 판단된다.

\section{미생물 동정}

미네랄 가용화능, 식물 생장 촉진 활성 및 항진균 활성을 고려 하여 최종적으로 다목적 기능을 가진 미생물 제제로써 가장 적 합한 DDP346 균주를 선정하였다. DDP346을 동정하기 위해서 $16 \mathrm{~S}$ rRNA 유전자 염기서열을 분석하여 NCBI Blast에서 비교 한 결과, Acinetobacter pittii DSM 21653 (NR_117621.1)과 $99.9 \%$ 로 높은 상동성을 보였다. $16 \mathrm{~S} \mathrm{rRNA}$ 염기서열을 바탕으 로 계통도를 분석한 결과(Fig. 1), Acinetobacter pittii와 높은 유연관계를 가지고 있는 것으로 확인되었으며, Bootstrap 값도 $77 \%$ 로 높은 수치를 보여 Acinetobacter sp.에 속하는 것으로 추 정된다.

\section{DDP346의 생장특성}

$\mathrm{DDP} 346$ 의 생장특성을 확인하기 위해서 다양한 온도와 $\mathrm{pH}$ 및 염 농도에서 배양하였다. 먼저, $0-50{ }^{\circ} \mathrm{C}$ 의 온도에서 배양한 결 과, DDP346 균주는 온도는 $10-40{ }^{\circ} \mathrm{C}$ 범위에서 생장 가능한 것 을 확인하였으며, 온도 범위 중에서도 $30{ }^{\circ} \mathrm{C}$ 에서 $\mathrm{DDP} 346$ 의 생 장이 가장 활발한 것으로 확인하였다. 이후 $30^{\circ} \mathrm{C}$ 의 $\mathrm{pH}$ 4-13 범위에서 측정한 결과 $\mathrm{pH} 5-11$ 범위에서 생장 가능한 것을 확 인하였다. 마지막으로 염 농도 $(\% \mathrm{NaCl})$ 는 $0-5 \%$ 의 범위에서 생 장 가능한 것을 확인하였으며(Fig. 2), 최종적으로 $30^{\circ} \mathrm{C}, \mathrm{pH}$ 6$7,0 \% \mathrm{NaCl}$ 에서 최적 생장조건임을 확인하였다.

\section{DDP346의 인산 가용화능}

DDP346를 배양하는 동안 배양 배지 내에 남아있는 glucose 함 량의 변화 및 배양 과정 중에 생성되는 유기산에 의한 $\mathrm{pH}$ 변
화와 가용화된 인산 함량 간의 상관관계를 확인하였다(Fig. 3). Glucose 함량은 배양 48시간까지 크게 감소하였으며, 배양이 진 행됨에 따라 $4 \mathrm{mg} / \mathrm{mL}$ 까지 꾸준히 감소하는 것을 확인하였다. 가용화된 인의 함량은 배양을 시작한지 24 시간 동안 $144.41 \mu \mathrm{g}$ $\mathrm{mL}$ 로 증가하였으며, 48 시간에서 $200.80 \mu \mathrm{g} / \mathrm{mL}$ 로 가장 높은 인 의 함량을 나타낸 후 72 시간까진 점진적으로 감소하였다. $\mathrm{pH}$ 는 배양을 시작한지 72시간까지는 지속적으로 떨어졌으며 72시간 이후부터 $\mathrm{pH}$ 가 다시 증가하였다. 일반적으로 미생물 배양 중에 생성되는 lactic, isovaleric, isobutyric, acetic, gluconic, citric, oxalic, tartaric, succinic 및 $\alpha$-ketogluconic acid 등과 같은 다 양한 종류의 유기산에 의해 토양과 근권 토양 내 불용성 인산 이 가용화 되며[12], 대부분의 그람 음성 박테리아는 glucose dehydrogenase 효소활성을 나타냄으로써 glucose를 gluconic acid로 산화시켜 인산 가용화능을 나타내는 것으로 알려져 있다 [31]. 따라서, DDP346 균주가 배양과정 중에 glucose를 gluconic acid로 산화시킴으로써 $\mathrm{pH}$ 가 낮아지고 생성된 gluconic acid에 의해 인산이 가용화된 것으로 추정된다. 이에 따라, $\mathrm{pH}$ 변화와 가용화된 인산 함량 간의 상관관계를 확인해 본 결과, $\mathrm{pH}$ 가 감 소됨에 따라 가용화된 인산의 함량이 증가하였으며 $\mathrm{r}^{2}=-0.913$ $(* * p<0.01)$ 로 높은 음의 상관관계를 나타내었다. El-Gibaly 등 [32]의 연구에서도 $\mathrm{pH}$ 변화와 가용화된 인산 함량 간에는 음의 상관관계를 가지며 직접적으로 산 생성과 관련이 있다고 보고 하였다. 따라서, DDP346의 인산 가용화능은 배양이 진행됨에 따라 생성되는 유기산에 기인되는 것으로 판단되며, 인산 이외 에도 미네랄 가용화능은 대부분 유기산에 의해 기인되는 것으 로 보아 탄산칼슘, 규소, 아연 가용화능에도 영향을 미친 것으 로 판단된다.

\section{DDP346의 효소활성 측정}

근권 미생물에 의해 분비되는 세포 외 효소는 식물과 병원균과 

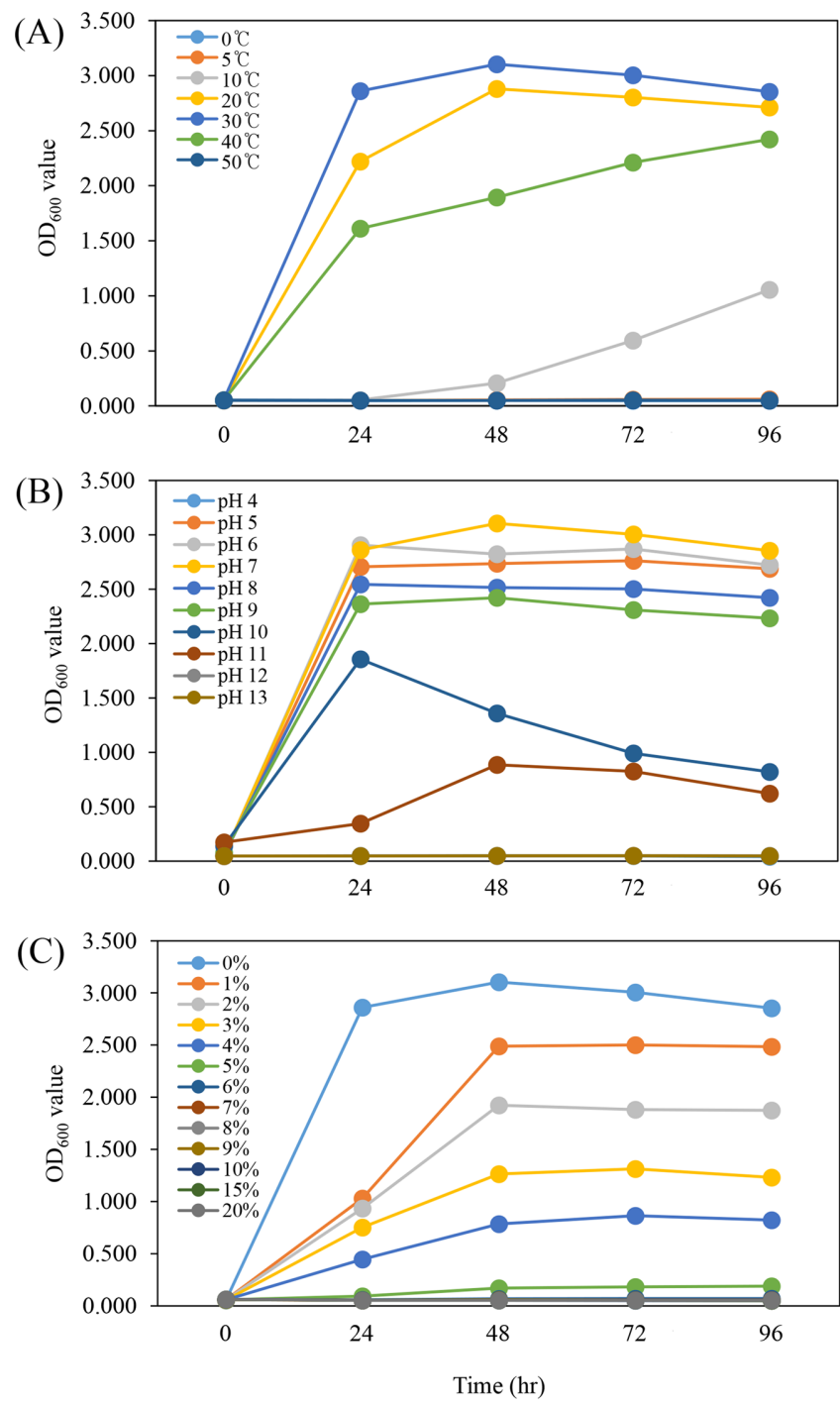

Fig. 2 Growth characteristics of DDP346. In order to confirm the growth characteristics, DDP346 strain was cultured in TSB medium at various condition of temperature $\left({ }^{\circ} \mathrm{C}\right), \mathrm{pH}, \mathrm{NaCl}$ concentration $(\%)$.Value are mean $\pm \mathrm{SD}(\mathrm{N}=3)$

의 상호작용을 통해 식물병을 억제하며, 미생물의 근권 정착 및 식물의 면역반응 등을 통해 식물의 생장에도 영향을 미치는 것 으로 알려져 있다[33]. DDP346의 세포 외 효소활성 측정 결과, amylase, cellulase, protease, xylanase 활성은 각각 16.91, $10.49,19.70,49.85 \mathrm{mg} / 100 \mathrm{~mL}$ 로 4 가지 가수분해효소 중에서는 xylanase 활성이 가장 높았다. 본 연구결과 DDP346은 4가지의 세포 외 효소를 가짐으로써 식물 병원성 곰팡이의 세포벽을 분 해하여 곰팡이의 생장을 억제하는 데 도움을 줄 수 있을 것으 로 추정된다. 이 외에도 $\mathrm{DDP} 346$ 이 갖는 효소활성을 확인하기 위해서 API ZYM kit를 이용하여 다양한 효소활성을 확인하였 다. 그 결과, esterase $(\mathrm{C} 4)$, esterase $(\mathrm{C} 8)$, leucine arylamidase, valine arylamidase, naphtol-AS-BI-phosphohydrolase 활성을 나 타냈으며, 그 중에서도 leucine arylamidase 활성이 높게 나타났 다. 따라서, DDP346 균주는 siderophore 생성능과 세포 외 효
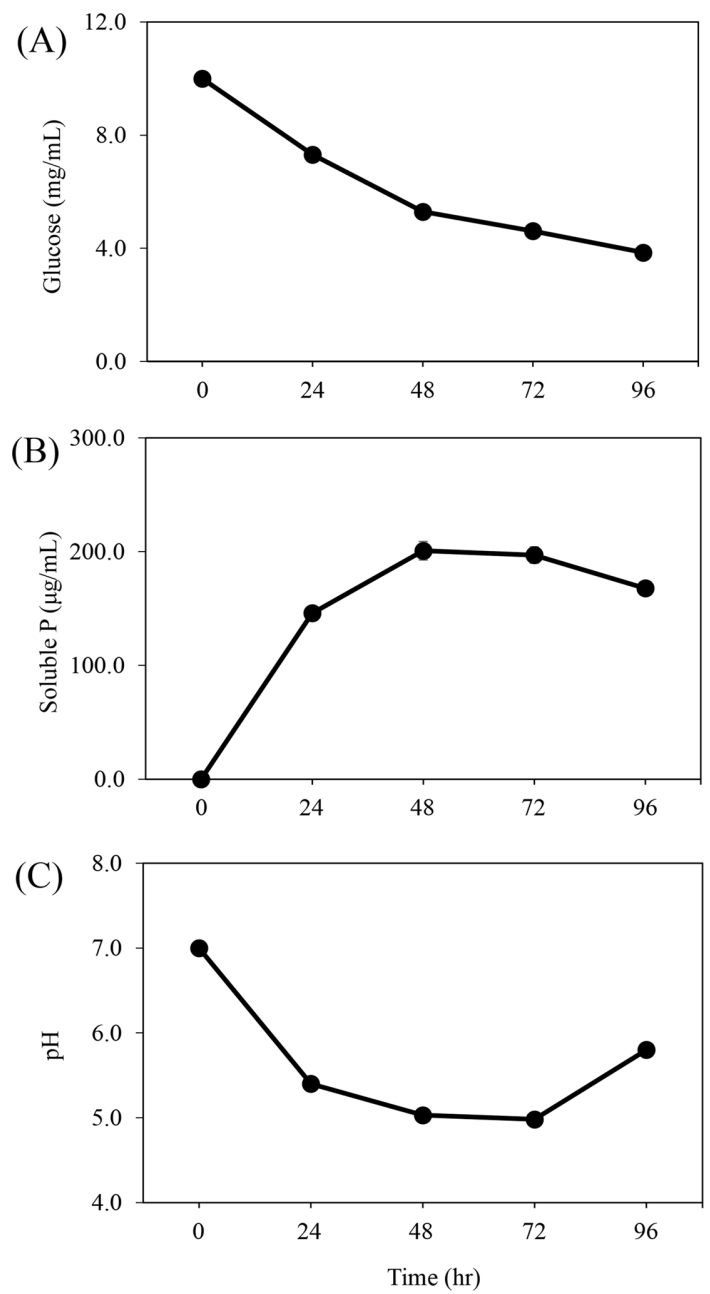

Fig. 3 Changes in glucose content, phosphate and $\mathrm{pH}$ according to culture time of Acinetobacter sp. DDP346. (A) Residual glucose content, (B) solubilized phosphate content, (C) $\mathrm{pH}$. Value are mean $\pm \mathrm{SD}(\mathrm{N}=3)$

소(amylase, cellulase, protease, xylanase) 및 다양한 효소활성 을 가짐으로써 식물 생장 촉진뿐만 아니라 식물 병원성 곰팡이 의 생장 억제에 도움을 줄 수 있을 것으로 판단된다.

본 연구는 다목적 기능을 가진 미생물 제제로의 활용 가능성 을 평가하기 위해서 수행하였다. 미생물 제제로써 활용 가능성 은 미네랄 가용화능, 항진균 활성, 항균 활성 및 식물 생장 촉 진 활성으로 평가하였다. 먼저 분리된 13 균주 중에서 미네랄 가 용화능(인산, 탄산칼슘, 규소, 아연)을 모두 가진 5균주(ANG37, $\mathrm{DDP} 77, \mathrm{DDP} 346, \mathrm{DDP} 398, \mathrm{DDP} 406)$ 를 1차적으로 선별하였다. 그 다음으로 항진균 활성과 항균 활성을 확인한 결과, $\mathrm{ANG} 37$ 와 $\mathrm{DDP} 346$ 균주는 각각 1 종과 7 종의 식물 병원성 곰팡이에 대해 항진균 활성을 나타내었으며, 1-2종의 식물 병원성 세균에 대해서도 항균 활성을 나타내었다. 식물 생장 촉진 활성은 5 균 주 모두 활성을 가지는 것으로 확인되었으며, 그 중에서도 $\mathrm{DDP} 346$ 은 질소 고정능과 IAA 생성능에서 비교적 높은 활성을 나타내었다. 따라서, 인산, 탄산칼슘, 규소, 아연 가용화능, 7 종 의 식물 병원성 곰팡이에 대해 항진균 활성 및 질소고정능, siderophore, IAA, ACC deaminase 생성능을 가진 Acinetobacter 
sp. DDP346 균주를 최종적으로 선정하였다. $\mathrm{DDP} 346$ 의 생장 조건을 확인한 결과, 다양한 온도 $\left(10-40{ }^{\circ} \mathrm{C}\right), \mathrm{pH}(5-11)$ 및 염 농도 $(0-5 \%)$ 에서 생장 가능한 것을 확인하였다. 또한 $\mathrm{pH}$ 변화와 가용화된 인산 함량 간에 음의 상관계수 $\left(\mathrm{r}^{2}=-0.913, p<0.01\right)$ 를 나타내는 것을 확인하였는데, 이는 배양 중에 생성되는 유기산 에 의한 것으로 추정된다. 결과적으로 미네랄 가용화능, 항진균 활성, 식물 생장 촉진 활성을 평가를 통해 Acinetobacter sp. $\mathrm{DDP} 346$ 균주의 미생물 제제로써의 활용 가능성을 확인하였으 며, 향후 제형 연구 및 최적화, 작물 재배를 통해 미생물 제제 로써 응용하기 위한 연구가 수행되어야 할 것으로 사료된다.

\section{초 록}

본 연구는 근권 토양 및 뿌리에 존재하는 근권 미생물 중 미생 물 제제로 적합한 균주를 선별하기 위해서 미네랄 가용화능, 10 종의 식물 병원성 곰팡이에 대한 항진균 활성 및 식물 생장 촉 진 활성을 평가하였다. 결과적으로 불용성 인산, 탄산칼슘, 규 소 및 아연 가용화능과 질소고정능, siderophore, indole-3-acetic acid와 aminocyclopropane-1-carboxylate deaminase 생성능 및 7종의 식물 병원성 곰팡이에 대해 항진균 활성을 갖는 DDP346 을 선별하였다. 선별된 DDP346은 Acinetobacter pittii DSM 21653 (NR 117621.1)와 99.9\% 이상의 높은 상동성을 보였으며, $16 \mathrm{~S}$ rRNA 염기서열을 바탕으로 계통도를 분석한 결과에서도 Acinetobacter pittii와 높은 유연관계를 나타내었다. DDP346의 생장 조건은 온도 $\left(10-40{ }^{\circ} \mathrm{C}\right), \mathrm{pH}(5-11)$ 염농도 $(0-5 \%)$ 범위로 확인하였다. 또한 $\mathrm{pH}$ 변화와 가용화된 인산 함량 간에 음의 상 관계수 $\left(\mathrm{r}^{2}=-0.913, p<0.01\right)$ 를 나타내는 것을 확인하였는데, 이 는 배양 중에 생성되는 유기산에 의한 것으로 추정된다. 결과 적으로 미네랄 가용화능, 식물 병원성 곰팡이에 대한 항진균 활 성 및 식물 생장 촉진 활성 평가를 통해 Acinetobacter sp. $\mathrm{DDP} 346$ 을 다목적 미생물 제제로써 활용 가능성을 제시한다.

Keywords 미네랄 가용화능 · 미생물 제제 · 식물 생장 촉진 근권 미생물 · Acinetobacter sp.

\section{References}

1. Basu A, Prasad P, Das SN, Kalam S, Sayyed RZ, Reddy MS, El Enshasy $\mathrm{H}$ (2021) Plant growth promoting rhizobacteria (PGPR) as green bioinoculants: recent developments, constraints, and prospects. Sustainability 13: 1140. doi: 10.3390/su13031140

2. Santoyo G, Urtis-Flores CA, Loeza-Lara PD, Orozco-Mosqueda M, Glick BR (2021) Rhizosphere colonization determinants by plant growth-promoting rhizobacteria (PGPR). Biology 10: 475. doi: 10.3390/ biology 10060475

3. Gupta A, Bano A, Rai S, Dubey P, Khan F, Pathak N (2020) Plant growth promoting rhizobacteria (PGPR): a sustainable agriculture to rescue the vegetation from the effect of biotic stress: a review. Lett Appl NanoBioScience 10: 2459-2465. doi: 10.1080/17429145.2013.779035

4. Etesami H, Adl SM (2020) Plant growth-promoting rhizobacteria (PGPR) and their action mechanisms in availability of nutrients to plants. In: Kumar M, Kumar V, Prasad R (ed). Phyto-microbiome in stress regulation. Berlin/Heidelberg, Germany, pp 147-203
5. Olanrewaju OS, Glick BR, Babalola OO (2017) Mechanisms of action of plant growth promoting bacteria. World J Microbiol Biotechnol 33: 197. doi: 10.1007/s11274-017-2364-9

6. Han JH, Shim HS, Shin JH, Kim KS (2015) Antagonistic activities of Bacillus spp. strains isolated from tidal flat sediment towards anthracnose pathogens Colletotrichum acutatum and C. gloeosporioides in South Korea. Plant Pathol J 31: 165-175. doi: 10.5423/PPJ.OA.03. 2015.0036

7. Kumawat N, Kumar R, Khandkar U, Yadav R, Saurabh K, Mishra J, Dotaniya M, Hans H (2019) Silicon (Si)- and Zinc (Zn)-solubilizing microorganisms: role in sustainable agriculture. In: Giri B, Prasad R, Wu QS, Varma A (ed) Biofertilizers for sustainable agriculture and environment. Soil Biology. Springer, Switzerland AG. pp 109-135

8. Jung JJ, Park WJ (2015) Acinetobacter species as model microorganisms in environmental microbiology: current state and perspectives. Appl Microbiol Biotechnol 99: 2533-2548. doi: 10.1007/s00253-015-6439-y

9. Khan SA, Hamayun M, Yoon HJ, Kim HY, Suh SJ, Hwang SK, Kim JM, Lee IJ, Choo YS, Yoon UH, Kong WS, Lee BM, Kim JG (2008) Plant growth promotion and Penicillium citrinum. BMC Microbiol 8: 231. doi: 10.1186/1471-2180-8-231

10. Pande A, Pandey P, Mehra S, Singh M, Kaushik S (2017) Phenotypic and genotypic characterization of phosphate solubilizing bacteria and their efficiency on the growth of maize. J Genet Eng Biotechnol 15: 379-391. doi: 10.1016/j.jgeb.2017.06.005

11. Tamilselvi SM, Thiyagarajan C, Uthandi S (2016) Calcite dissolution by Brevibacterium sp. SOTI06: a futuristic approach for the reclamation of calcareous sodic soils. Front Plant Sci. 7: 1828. doi: 10.3389/fpls.2016. 01828

12. Kang SM, Waqas M, Shahzad R, You YH, Asaf S, Khan MA, Lee KE, Joo GJ, Kim SJ, Lee IJ (2017) Isolation and characterization of a novel silicate-solubilizing strain Burkholderia eburnea CS4-2 that promotes growth of japonica rice (Oryza sativa L. cv. Dongjin). J Soil Sci Plant Nutr 63: 233-241. doi: 10.1080/00380768.2017.1314829

13. Ranmesh A, Sharma SK, Sharma MP, Yadav N, Joshi OP (2014) Inoculation of zinc solubilizing Bacillus aryabhattai strains for improved growth, mobilization and biofortification of zinc in soybean and wheat cultivated in vertisols of central India. Appl Soil Ecol 73: 87-96. doi: 10.1016/j.apsoil.2013.08.009

14. Kim HS, Kim JY, Lee SM, Park HJ, Lee SH, Jang JS, Lee MH (2019) Isolation and characterization of indole-3-acetic acid and 1aminocylopropane-1-carboxylyic acid deaminase-producing bacteria related to environmental Stress. Microbiol Biotechnol Lett 47: 390-400. doi: $10.4014 / \mathrm{mbl} .1904 .04002$

15. Um YR, Kim BR, Jeong JJ, Chung CM, Lee Y (2014) Identification of endophytic bacteria in Panax ginseng seeds and their potential for plant growth promotion. Korean J Med Crop Sci 22: 306-312. doi: 10.7783/ KJMCS.2014.22.4.306

16. Milagres AMF, Machuca A, Napoleao D (1999) Detection of siderophore production from several fungi and bacteria by a modification of chrome azurol S (CAS) agar plate assay. J Microbiol Methods 37: 16. doi: 10.1016/s0167-7012(99)00028-7

17. Leveau JHJ, Lindow SE (2005) Utilization of the plant hormone indole3-acetic acid for growth by Pseudomonas putida strain 1290. Appl Environ Microbiol 71: 2365-2371. doi: 10.1128/AEM.71.5.2365-2371. 2005

18. Barnawal D, Bharti N, Maji D, Chanotiya C, Kalra A (2014) ACC deaminase-containing Arthrobacter protophormiae induces $\mathrm{NaCl}$ stress tolerance through reduced ACC oxidase activity and ethylene production resulting in improved nodulation and mycorrhization in Pisum sativum. $\mathrm{J}$ Plant Physiol 171: 884-894. doi: 10.1016/j.jplph.2014.03.007

19. Lee KH, Song HG (2007) Growth promotion of tomato seedlings by application of Bacillus sp. isolated from rhizosphere. Korean J Microbiol 43: $279-284$

20. Park JH, Han CH, Yoon MH (2017) Synergistic effect of phosphate solubilization by Burkholderia strains isolated from button mushroom 
bed. J Mushrooms 15: 183-189. doi: 10.14480/JM.2017.15.4.183

21. Miller GL (1959) Use of dinitrosalicylic acid reagent for determination of reducing sugar. Anal Chem 31: 426-428. doi: 10.1021/ac60147a030

22. Shin PY, Cho SJ (2011) Cellulase and xylanase activity of compostpromoting bacteria Bacillus sp. SJ21. Korean J Soil Sci Fert 44: 836840. doi: 10.7745/KJSSF.2011.44.5.836

23. Oh DG, Jang YK, Woo JE, Kim JS, Lee CH (2016) Metabolomics reveals the effect of garlic on antioxidant- and protease-activities during Cheonggukjang (fermented soybean paste) fermentation. Food Res Int 82: 86-94. doi: 10.1016/j.foodres.2016.01.019

24. Rodriguez PA, Rothballer M, Chowdhury SP, Nussbaumer T, Gutjahr C, Falter-Braum P (2019) Systems biology of plant-microbiome interactions. Molecular Plant 12: 804-821. doi: 10.1016/j.molp.2019.05.006

25. Zarraonaindia I, Owens SM, Weisenhorn P, West K, Hampton-Marcell J, Lax S, Bokulich NA, Mills DA, Martin G, Taghavi S, van der Leli D, Gilber JA (2015) The soil microbiome influences grapevine-associated microbiota. mBio 6: e02527-14. doi: 10.1128/mBio.02527-14

26. Penroe DM, Glick BR (2003) Methods for isolating and characterizing ACC deaminase-containing plant growth-promoting rhizobacteria. Physiol Plant 118: 10-15. doi: 10.1034/j.1399-3054.2003.00086.x

27. Lee SM, Chung JH, Ryu CM (2015) Augmenting plant immune responses and biological control by microbial determinants. Res Plant Dis 21: 161-179. doi: 10.5423/RPD.2015.21.3.161

28. Aloo BN, Makumba BA, Mbega ER (2019) The potential of bacilli rhizobacteria for sustainable crop production and environmental sustainability. Microbiol Res 219: 26-39. doi: 10.1016/j.micres.2018. 10.011

29. Danish S, Zafar-ul-Hye M, Mohsin F, Hussain M (2020) ACCdeaminase producing plant growth promoting rhizobacteria and biochar mitigate adverse effects of drought stress on maize growth. PLoS One 15: e0230615. doi: 10.1371/journal.pone.0230615

30. Vimal SR, Patel VK, Singh JS (2019) Plant growth promoting Curtobacterium albidum strain SRV4: an agriculturally important microbe to alleviate salinity stress in paddy plants. Ecol Indic 105: 553562. doi: 10.1016/j.ecolind.2018.05.014

31. Suleman M, Yasmin S, Rasul M, Yahya M, Atta BM, Mirza MS (2018) Phosphate solubilizing bacteria with glucose dehydrogenase gene for phosphorus uptake and 500 beneficial effects on wheat. PLoS One 13: e0204408. doi: 10.1371/journal.pone.0204408

32. El-Gibaly MH, Reweiny FM, Abdel-Nasser M, El-Dahtory TA (1977) Studies on phosphate-solubilizing bacteria in soil and dissolvers and their morphological grouping. Zlb Bakt II Abt Bd 132: 240-244. doi: 10.1016/s0044-4057(77)80007-5

33. Park KH, Park HW, Lee SW, Lee SH, Myung KS, Lee SY, Song JK, Kim YT, Park KS, Kim YO (2016) Isolation and characterization of Bacillus species having antifungal activity against pathogens of ginseng damping off. Korean J Pestic Sci 20: 380-387. doi: 10.7585/kjps.2016. 20.4.380 